\title{
PENGARUH PENGKAYAAN NUTRISI PADA \\ CACING SUTERA (Tubifex spp) SEBAGAI PAKAN LARVA \\ IKAN PATIN (Pangasius hypopthalmus) TERHADAP LAJU PERTUMBUHAN
}

\author{
Oleh \\ Sujono*, Edward Danakusumah**, Dwi Ernaningsih** \\ *Staff Jurusan Penyuluhan Perikanan Sekolah Tinggi Perikanan \\ **Dosen Universitas Satya Negara Indonesia Jakarta
}

\begin{abstract}
ABSTRAK
Perlakuan dalam pembenihan ikan patin sudah banyak dilakukan oleh para pembenih tetapi sampai saat ini masih banyak kendala yang dihadapi hal ini disebabkan pada waktu pemberian pakan cacing sutera (Tubifex sp) pada stadia larva sampai saat ini masih banyak mengalami permasalahan dengan pertumbuhan yang lambat. Hal ini diperkirakan kurangnya nilai nutrisi pada pakan yang diberikan,dengan pertimbangan ini maka perlu adanya suatu kajian cara lain untuk mengatasi masalah ini yang diantaranya penggunaan kuning telur ayam sebagai alternatif penambahan nutrisi pada cacing sutera sebagai pakan, dengan cara cacing sutra dipuasakan terlebih dahulu lalu diberikan kuning telur ayam kampung yang telah direbus sebagai makanan bagi cacing sutera.

Tujuan penelitian adalah untuk mengetahui pengaruh pengkayaan nutrisi pada cacing sutera sebagai pakan larva ikan patin terhadap laju pertumbuhan. Adapun manfaat penelitian adalah sebagai sumber informasi atau acuan kepada pembudidaya khususnya usaha pembenihan ikan patin, dan alternatif teknologi yang dapat diterapkan.

Pengkayaan nutrisi pada cacing sutera dengan kuning telur ayam kampung dapat memberikan dampak yang baik pada laju pertumbuhan. Hal ini terlihat dari perlakuan E (8 jam pengkayaan nutrisi cacing sutera) dengan pertambahan bobot rata-rata $1.76 \pm 0.09$ gram dan pertambahan panjang pada perlakuan E ( 8 jam pengkayaan nutrisi cacing sutera) dengan pertambahan panjang rata-rata $2.35 \pm 0.13 \mathrm{~cm}$ dibandingkan dengan perlakuan A (control) $0.96 \pm 0.16$ gram dan pertambahan panjang $2.0 \pm 0.07 \mathrm{~cm}$.
\end{abstract}

Kata kunci : Larva ikan patin, cacing sutera, pengkayaan, kuning telur ayam kampung

\section{PENDAHULUAN}

\section{Latar Belakang}

Ikan patin (Pangasius

hypopthalmus) merupaka salah satu jenis ikan yang popular di masyarakat. Ikan ini berasal dari Thailand dan pertama kali didatangkan ke Indonesia pada tahun 1972 oleh Balai Penelitian Perikanan Air Tawar Bogor. Sebutan lain ikan patin siam adalah lele Bangkok atau pangasius dan di negara asalnya disebut "Pla Sawai". Ikan patin sangat lezat dimasak sebagai gulai, pepes atau masakan kuah lainnya. Berbagai langkah terus dilakukan mulai dari perbaikan sarana dan prasarana, penyediaan induk serta benih berkualitas, serta pengelolaan komponen-komponen budidaya dalam setiap tahapan kegiatan.

Direktorat Jenderal Pengolahan dan Pemasaran Hasil Perikanan (P2HP) Kementrian Kelautan dan Perikanan (KKP) memberitahukan bahwa masyarakat Amerika Serikat selalu menginginkan ikan patin siam yang diekspor ke negara itu harus memiliki 
berat rata-rata satu kilogram per ekor. Hal ini merupakan tantangan bagi pembudidaya ikan patin siam untuk menghasilkan benih-benih yang berkualitas, sehingga mampu menghasilkan ikan konsumsi dengan berat sesuai dengan target. Tanggung jawab utama menciptakan iklim investasi dan usaha budidaya perikanan menjadi kondusif tidak semata-mata berada pada masyarakat, investor, atau KKP. Investasi juga menuntut dukungan infrastruktur dasar, seperti listrik dan jalan yang memadai. Demikian pula masyarakat pembudidaya sangat membutuhkan modal usaha dari perbankan.

Keberhasilan setiap tahapan kegiatan budidaya ikan patin dipengaruhi oleh berbagai faktor, antara lain pengadaan benih unggul yang harus tersedia kontinyu dan memenuhi kebutuhan, saat ini banyak kendala yang dihadapi oleh para pembenih terutama pada stadia larva yang mengalami banyak pertumbuhan yang lambat dan kematian. Berbagai langkah pencegahan dan penanggulangan telah dilakukan untuk mengatasi hal ini, yang salah satunya adalah penebaran larva dengan kepadatan rendah. Namun demikian, pada pelaksanaan di tingkat pembenih (hatchery), seringkali ditemukan kasus kematian larva secara masal, pada saat pergantian pakan dari artemia ke cacing sutera (Tubifex sp) sehingga mengakibatkan ketidak berhasilan dalam pembenihan. Apabila hal ini terjadi dalam jangka waktu lama akan menimbulkan pengaruh negatif bagi para pembdidaya ikan patin, berkenaan dengan hal tersebut, maka dicari berbagai langkah alternatif, diantaranya adalah pengkayaan nutrisi pada cacing sutera dengan pemberian kuning telur ayam yang telah direbus terlebih dahulu.

\section{Rumusan Masalah}

Perlakuan dalam pembenihan ikan patin sudah banyak dilakukan oleh para pembenih tetapi sampai saat ini masih banyak kendala yang dihadapi hal ini disebabkan pada waktu pemberian pakan cacing sutera (Tubifex sp) pada stadia larva sampai saat ini masih banyak mengalami permasalahan dengan pertumbuhan yang lambat. Hal ini diperkirakan kurangnya nilai nutrisi pada pakan yang diberikan,dengan pertimbangan ini maka perlu adanya suatu kajian cara lain untuk mengatasi masalah ini yang diantaranya penggunaan kuning telur ayam sebagai alternatif penambahan nutrisi pada cacing sutera sebagai pakan, dengan cara cacing sutra dipuasakan terlebih dahulu lalu diberikan kuning telur ayam yang telah direbus sebagai makanan bagi cacing sutera.

\section{Tujuan dan Manfaat Penelitian}

Tujuan penelitian adalah untuk mengetahui pengaruh pengkayaan nutrisi pada cacing sutera sebagai pakan larva ikan patin terhadap laju pertumbuhan. Manfaat penelitian adalah sebagai sumber informasi atau acuan kepada pembudidaya khususnya usaha pembenihan ikan patin, dan alternatif teknologi yang dapat diterapkan.

\section{Hipotesis}

Pengkayaan nutrisi dengan kuning telur ayam kampung yang direbus pada cacing sutera sebagai pakan larva ikan patin diharapkan memberikan efek positip terhadap pertumbuhan dengan mengunakan hipotesis :

$\mathrm{H}_{0}$ : pemberian kuning telur pada cacing sutera sebagai pakan larva ikan patin 
tidak berpengaruh terhadap Desember 2013 sampai dengan tanggal pertumbuhan 10 Januari 2014 di Hatchery Sekolah

$\mathrm{H}_{1}$ : pemberian kuning telur pada cacing sutera sebagai pakan larva ikan patin berpengaruh terhadap pertumbuhan

\section{METODOLOGI}

\section{Waktu dan Tempat}

Penelitian ini telah dilaksanakan Tinggi Perikanan Jurusan Penyuluhan Perikanan.

\section{Bahan dan Alat Penelitian}

Bahan yang digunakan dalam penelitian dapat dilihat pada Tabel 1.

Tabel 1. Bahan Penelitian

\begin{tabular}{lll}
\hline No & Jenis Bahan & Kegunaan/Manfaat \\
\hline 1 & Larva ikan patin & Sebagai hewan uji \\
2 & Telur Ayam kampung & Digunakan untuk pengkayaan nutrisi pada cacing \\
& & sutera \\
3 & Garam kristal & Digunakan untuk sterilisasi \\
4 & Cacing sutera & Sebagai pakan larva ikan patin \\
\hline
\end{tabular}

Alat yang digunakan dalam penelitian dapat dilihat pada Tabel 2.

Tabel 2. Alat-alat yang Digunakan dalam Penelitian

\begin{tabular}{lll}
\hline No & Jenis Alat & Kegunaan/Manfaat \\
\hline 1 & Timbangan digital $1.000 \mathrm{~g}$ & Untuk menimbang larva dan garam \\
2 & Baskom besar & $\begin{array}{l}\text { Tempat pengkayaan nutrisi pada cacing } \\
\text { sutera }\end{array}$ \\
& & Wadah pemberian pakan \\
3 & Ember & Tempat pemeliharaan larva \\
4 & Akuarium $80 \times 40 \times 35 \mathrm{~cm}$ & Suplai oksigen \\
5 & Blower & Untuk panen benih \\
6 & Serokan & Untuk menghitung larva \\
7 & Caunter & Untuk mengukur pH \\
9 & pH Tes & Untuk mengukur temperatur \\
10 & Termometer & \\
\hline
\end{tabular}

\section{METODE PENELITIAN}

\section{Rancangan Acak Lengkap (RAL)}

Penelitian ini mengunakan
Acak Lengkap (RAL) dengan perlakuan A, B, C, D dan E masing-masing diulang empat kali. Adapun rincian dari setiap perlakuan adalah sebagai berikut :

rancangan percobaan berupa Rancangan

Perlakuan A $\quad$ : Cacing sutera tanpa perlakuan sebagai kontrol

Perlakuan B $\quad$ : Cacing sutera yang diberi pakan kuning telur ayam kampung selama 1 jam sebagai pengkayaan nutrisi

Perlakuan $\mathrm{C} \quad$ : Cacing sutera yang diberi pakan kuning telur ayam kampung selama 2 jam sebagai pengkayaan nutrisi

Perlakuan D $\quad$ : Cacing sutera yang diberi pakan kuning telur ayam kampung selama 4 jam sebagai pengkayaan nutrisi

Perlakuan E $\quad$ : Cacing sutera yang diberi pakan kuning telur ayam kampung selama 8 jam sebagai pengkayaan nutrisi 
Nilai-nilai pangamatan hasil percobaan (Y) menurut rancangan bergalat tunggal ini, model Rancangan Acak Lengkap yang digunakan adalah sebagai berikut (Gomesz, 1995)

$$
Y=\mu+\tau+\varepsilon
$$

$\begin{array}{cl}\text { Keterangan : } & \\ \mu & : \text { nilai rerata (mean) harapan } \\ \tau & : \text { Pengaruh faktor perlakuan } \\ \varepsilon & : \text { Pengaruh galat (experimental error) }\end{array}$

\section{Peubah yang Diukur}

Peubah yang diukur dalam penelitian ini adalah pertambahan bobot (gram), pertambahan panjang $(\mathrm{cm})$ dan tingkat kelangsungan hidup (\%) larva ikan patin. Rumus dari peubah tersebut adalah :

\section{Pertambahan bobot (gram)}

Pertumbuhan bobot mutlak dapat dihitung dengan menggunakan rumus Effendie (1979) yaitu :

$\mathrm{Wm}=\mathrm{Wt}-\mathrm{Wo}_{\mathrm{o}}$

Dimana :

Wm : Pertumbuhan berat mutlak (g).

Wt : Bobot akhir (g)

Wo : Bobot akhir (g)

\section{Pertambahan panjang (cm)}

Pertambuhan panjang mutlak $(\mathrm{cm})$ ditentukan berdasarkan selisih panjang akhir (Lt) dengan panjang awal (Lo) pemeliharaan. Pertambuhan panjang dihitung berdasarkan rumus berikut (Effendie, 1979)

$\mathrm{Pm}=\mathrm{Lt}-\mathrm{Lo}$

Keterangan :

Pm : Pertambuhan panjang mutlak (cm)

Lt : Panjang rata-rata akhir $(\mathrm{cm})$

Lo : Panjang rata-rata awal $(\mathrm{cm})$

\section{Tingkat kelangsungan hidup (\%)}

Menurut Effendie (1997), tingkat kelangsungan hidup dinyatakan dalam persentase dari organisme yang hidup pada awal dan akhir penelitian dan dirumuskan sebagai berikut :

$\mathrm{SR}=(\mathrm{Nt} / \mathrm{No}) \times 100 \%$

Keterangan :

SR : Tingkat kelangsungan hidup (\%)

$\mathrm{Nt}$ : Jumlah ikan yang hidup pada akhir pengamatan (ekor)

No : Jumlah ikan yang hidup pada awal pengamatan (ekor)

\section{Asumsi}

Asumsi yang diajukan pada penelitian ini adalah :

a. Kondisi larva setiap ikan uji dianggap sama

b. Tingkat keseragaman ikan uji dianggap sama

c. Tingkat ketelitian peneliti dianggap sama

\section{Analisis Data}

Data yang diperoleh dari hasil penelitian akan duji normalitas dan homogenitas, selanjutnya dianalisis mengunakan analisis varians (ANOVA). Bila hasil uji menunjukkan adanya perbedaan nyata diantara masing-masing 
perlakuan maka akan dilanjutkan dengan

uji BNT (Beda Nyata Terkecil atau LSD)

\section{Prosedur Penelitian}

Persiapan Wadah

Wadah yang digunakan dalam berukuran $80 \times 40 \times 35 \mathrm{~cm}$, akuarium dicuci dan disterilkan dengan diterjen lalu dikeringkan selama 24 jam. Langkah selanjutnya akuarium diisi air setinggi 25 $\mathrm{cm}$ dan dipasang airasi sebagai suplay oksigen terlarut pada media penelitian. penelitian adalah akuarium 20 buah

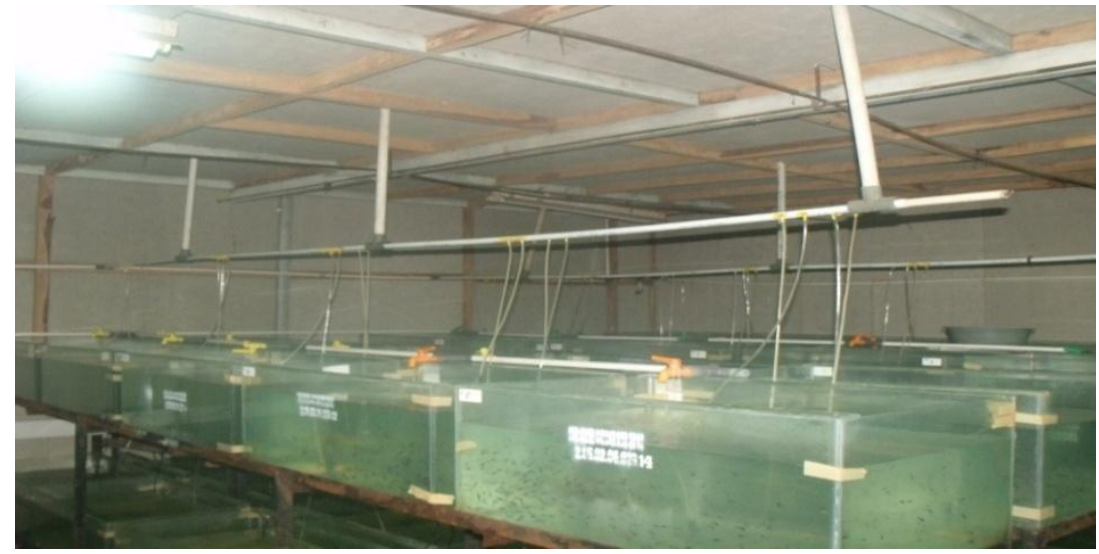

Gambar 1. Akuarium Wadah Penelitian

\section{Ikan Uji}

Ikan uji adalah larva ikan patin yang baru berumur 3 hari dengan berat $0.2 \mathrm{~g}$ dan panjang $3 \mathrm{~mm}$ serta padat tebar 1.000 ekor/akuarium. Ikan uji ini berasal dari unit pembenihan ikan patin Omega Outlet yang berlokasi Kecamatan Ciseeng Kabupaten Bogor.

\section{Pengkayaan nutrisi pada cacing suteraa dengan kuning telur ayam kampung}

Cacing sutera dibersihkan dari lumpur hingga benar-benar bersih, lalu dipuasakan selama 24 jam. Hari berikutnya cacing sutera diberi pakan kuning telur ayam kampung yang telah direbus sesuai dengan perlakuan. Perlakuan A (kontrol tanpa pemberian kuning telur), B (pemberian pakan selama 1 jam), C (pemberian pakan selama 2 jam), D (pemberian pakan selama 4 jam), dan E (pemberian pakan selama 8 jam). Langkah selajutnya cacing sutera dipanen dan dicincang sampai halus dan dicuci hingga bersih lalu disimpan pada suhu rendah $\left(0-1^{\circ} \mathrm{C}\right)$ sehingga tidak mengalami pembusukan. Proses pengkayaan nutrisi pada cacing sutera dapat dilihat pada Gambar 2. 


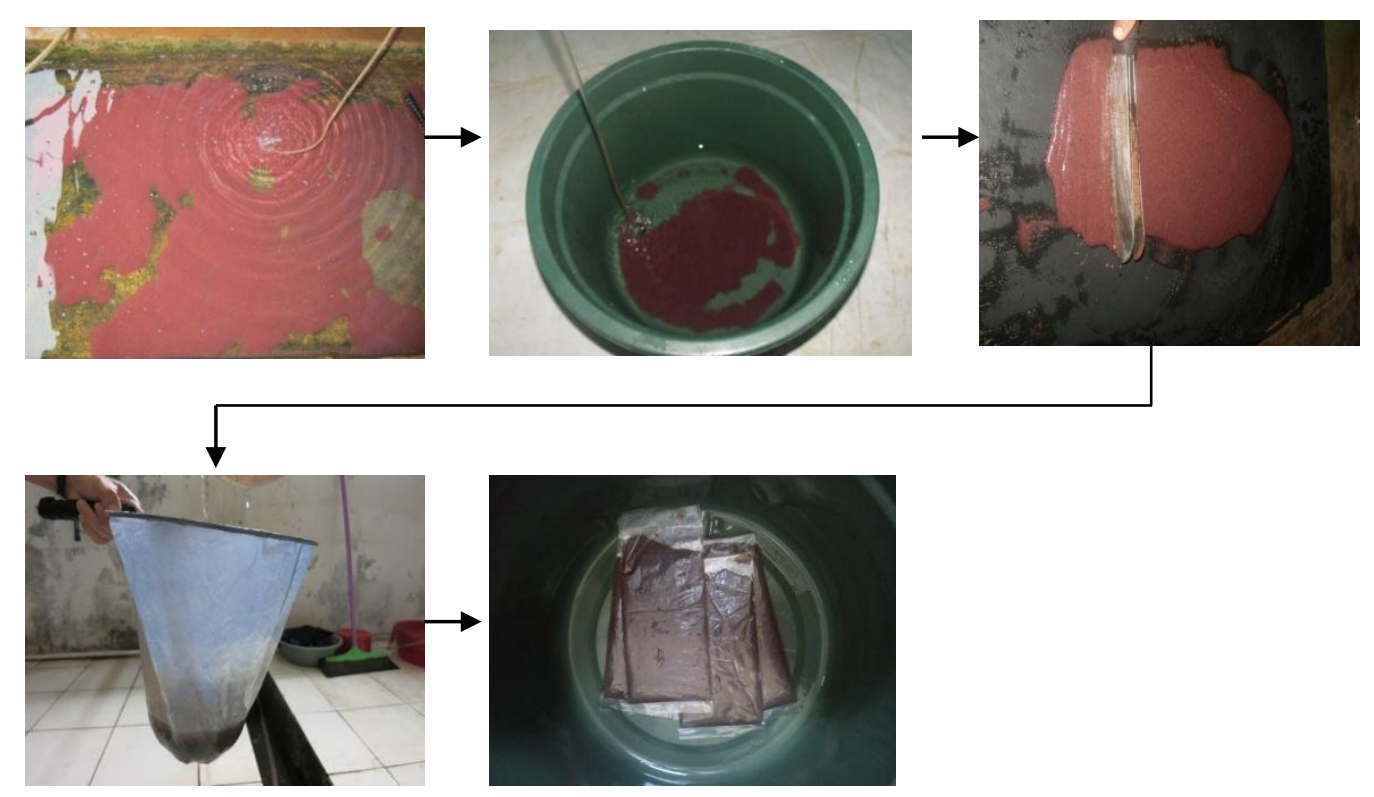

Gambar 2. Alur Proses Pengkayaan Nutrisi pada Cacing Sutera

\section{Kualitas Air}

Kualitas air yang diukur sebagai pendukung dalam penelitian ini antara lain oksigen terlarut (DO), $\mathrm{pH}$ dan suhu.

\section{HASIL DAN PEMBAHASAN}

\section{Pertambahan Bobot, Panjang dan Tingkat Kelangsungan Hidup}

Laju pertumbuhan meliputi pertambahan bobot, panjang serta tingkat kelangsungan hidup pada larva ikan patin. Pertumbuhan merupakan perpaduan antara proses perubahan struktur melalui peningkatan biomassa sebagai proses transformasi materi dari energi pakan menjadi massa tubuh (Yamaoka dan Scheer, 1970). Persentase pakan yang diubah menjadi daging atau pertambahan bobot ikan yang dipelihara berkaitan erat dengan jenis pakan yang dimakan.

\section{Pertambahan bobot (g)}

Data analisis pertambahan bobot larva ikan patin selama penelitian dari masing-masing perlakuan tersaji pada Tabel 3.

Tabel 3. Pertambahan Bobot

\begin{tabular}{ccc}
\hline Perlakuan & $\begin{array}{c}\text { Rata-rata Pertambahan } \\
\text { Bobot }(\mathbf{g})\end{array}$ & Standar Deviasi \\
\hline A & $0,80-1,12$ & $0,96 \pm 0,16$ \\
B & $1,00-1,32$ & $1,16 \pm 0,16$ \\
C & $0,86-1,36$ & $1,11 \pm 0,25$ \\
D & $1,04-1,42$ & $1,23 \pm 0,19$ \\
E & $1,67-1,85$ & $1,76 \pm 0,09$ \\
\hline
\end{tabular}

Keterangan :

A : Cacing sutera tanpa perlakuan sebagai kontrol

B : Cacing sutera yang diberi pakan kuning telur ayam kampung selama 1 jam sebagai pengkayaan nutrisi

$\mathrm{C}$ : Cacing sutera yang diberi pakan kuning telur ayam kampung selama 2 jam sebagai pengkayaan nutrisi 

D : Cacing sutera yang diberi pakan kuning telur ayam kampung selama 4 jam sebagai pengkayaan nutrisi
E : Cacing sutera yang diberi pakan kuning telur ayam kampung selama 8 jam sebagai pengkayaan nutrisi

Berdasarkan Tabel 3 menunjukan bahwa pengkayaan nutrisi pada cacing sutera dengan kuning telur ayam kampung sebagai pakan larva ikan patin memberikan perbedaan terhadap pertambahan bobot $(\mathrm{g})$. Pertambahan bobot tertinggi terdapat pada perlakuan E dengan rata-rata pertambahan bobot $1,67-1,85 \mathrm{~g}$, di ikuti dengan perlakuan D dengan pertambahan bobot rata-rata $1,04-1,42 \mathrm{~g}, \mathrm{~B}$ dengan pertambahan bobot rata-rata $1,00-1,32 \mathrm{~g}, \mathrm{C}$ dengan bobot rata-rata $0,86-1,36 \mathrm{~g}$, dan A (kontrol) dengan pertambahan bobot $0,80-1,12 \mathrm{~g}$.

Pengkayaan nutrisi pada cacing sutera dengan kuning telur ayam kampung sebagai pakan larva ikan patin memberikan dampak pertumbuhan yang baik. Hal ini terlihat dari masing-masing perlakuan, diduga dengan adanya pengkayaan nutrisi pada cacing sutera memberikan nilai tambahan gizi. Pada perlakuan $\mathrm{E}$ (8 jam pengkayaan) memberikan pertumbuhan tertinggi yaitu 1,67-1,85 g, hal ini diduga dengan adanya pengkayaan nutrisi pada cacing sutera dengan kuning telur ayam kampung selama 8 jam pada perlakuan $\mathrm{E}$ memberikan waktu yang cukup bagi cicing sutera untuk dapat mencerna dan menyerap nilai nutrisi yang terdapat pada kuning telur ayam kampung yang diberikan sebagai pakan, sehingga memberikan nilai tambah nutrisi pada cacing sutera sebagai pakan larva ikan patin dan memberikan dampak pertumbuhan pada larva ikan patin lebih cepat dibanding dengan perlakuan yang lain kondisi ini didukung oleh Kordi (2005) yang menyatakan bahwa larva ikan patin sebagaimana hewan air lainnya untuk memperoleh pertumbuhan maksimal membutuhkan asupan makanan yang unsur-unsurnya (protein, karbohidart, lemak dan lain-lainnya) mencukupi hewan tersebut. Padat tebar yang tinggi akan mengganggu laju pertumbuhan meskipun kebutuhan makanan tercukupi. Hal ini disebabkan karena adanya persaingan dalam memperebutkan makanan dan ruang.

Berdasarkan analisis ragam diperoleh hasil bahwa perbedaan perlakuan pengkayaan nutrisi pada cacing sutera dengan kuning telur ayam kampung sebagai pakan larva ikan patin terhadap pertambahan bobot memberikan pengaruh nyata $(\mathrm{p}>0.05)$. Hal ini terlihat bahwa $\mathrm{F}$ hitung $(12,33)$ lebih besar dari pada $\mathrm{F}$ tabel $(3,06)$. Hasil uji BNT terlihat ada perbedaan nyata dari masing-masing perlakuan terhadap pertambahan bobot larva patin. Beda Nyata Terkecil pada pertambahan bobot sebesar $0.26 \mathrm{~g}$ dapat dilihat Gambar 7. 


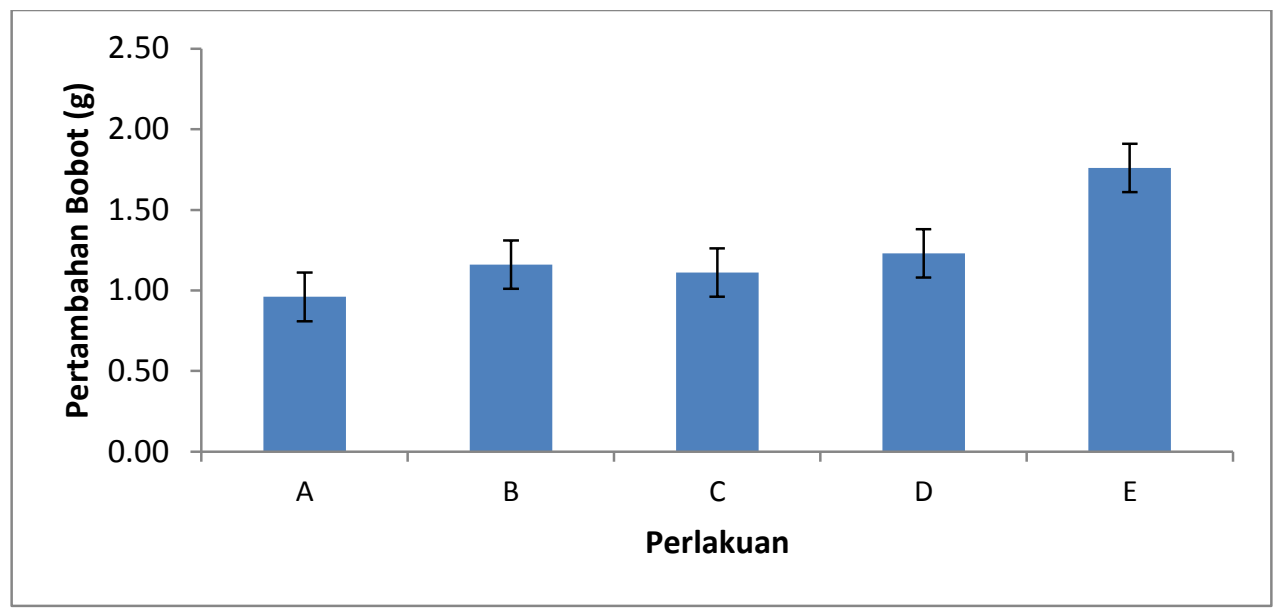

Gambar 3. Hasil Uji BNT pada Setiap Perlakuan Terhadap Pertambahan Bobot

\section{Pertambahan Panjang}

Data analisis pertambahan panjang larva ikan patin selama penelitian dari masing-masing perlakuan tersaji pada Tabel 4.

Tabel 4. Pertambahan Panjang

\begin{tabular}{ccc}
\hline Perlakuan & $\begin{array}{c}\text { Rata-rata Pertambahan } \\
\text { Panjang }(\mathbf{c m})\end{array}$ & Standar Deviasi \\
\hline A & $1,94-2,08$ & $2,01 \pm 0,07$ \\
B & $2,12-2,28$ & $2,20 \pm 0,08$ \\
C & $2,02-2,18$ & $2,10 \pm 0,08$ \\
D & $2,03-2,23$ & $2,13 \pm 0,10$ \\
E & $2,22-2,48$ & $2,35 \pm 0,13$ \\
\hline
\end{tabular}

Berdasarkan Tabel 4 menunjukan bahwa pengkayaan nutrisi pada cacing sutera dengan kuning telur ayam kampung sebagai pakan larva ikan patin memberikan perbedaan terhadap pertambahan panjang $(\mathrm{cm})$. Pertambahan panjang tertinggi terdapat pada perlakuan $\mathrm{E}$ dengan rata-rata panjang $2,22-2,48 \mathrm{~cm}$ yang diikuti perlakuan $\mathrm{D}$ $=2,03-2,23 \mathrm{~cm}$, perlakuan $\mathrm{B}=2,12-$ $2,28 \mathrm{~cm}$, perlakuan $\mathrm{C}=2,02-2,18 \mathrm{~cm}$ dan perlakuan $\mathrm{A}=1,94-2,08 \mathrm{~cm}$. Pengkayaan nutrisi pada cacing sutera dengan kuning telur ayam kampung sebagai pakan larva ikan patin juga memberikan dampak positif pada pertumbuhan pertambahan panjang. Hal ini terlihat dari masing-masing perlakuan, diduga dengan adanya pengkayaan nutrisi pada cacing sutera memberikan nilai tambahan nutrisi, sehingga besar kemungkinan dapat memberikan pertumbuhan yang maksimal karena asupan makanan yang unsur-unsurnya (protein, karbohidart, lemak dan lain-lainnya) mencukupi.

Perbedaan perlakuan pengkayaan nutrisi pada cacing sutera dengan kuning telur ayam kampung sebagai pakan larva ikan patin terhadap pertambahan panjang memberikan pengaruh nyata $(\mathrm{p}>0,05)$. Hal ini terlihat bahwa F hitung (7) lebih besar dari pada $F$ tabel $(3,06)$. Hasil uji BNT terlihat ada perbedaan nyata dari 
tiap masing-masing perlakuan panjang sebesar $0.15 \mathrm{~cm}$ dapat dilihat pertambahan panjang larva patin. Beda pada Gambar 4.

Nyata Terkecil pada pertambahan

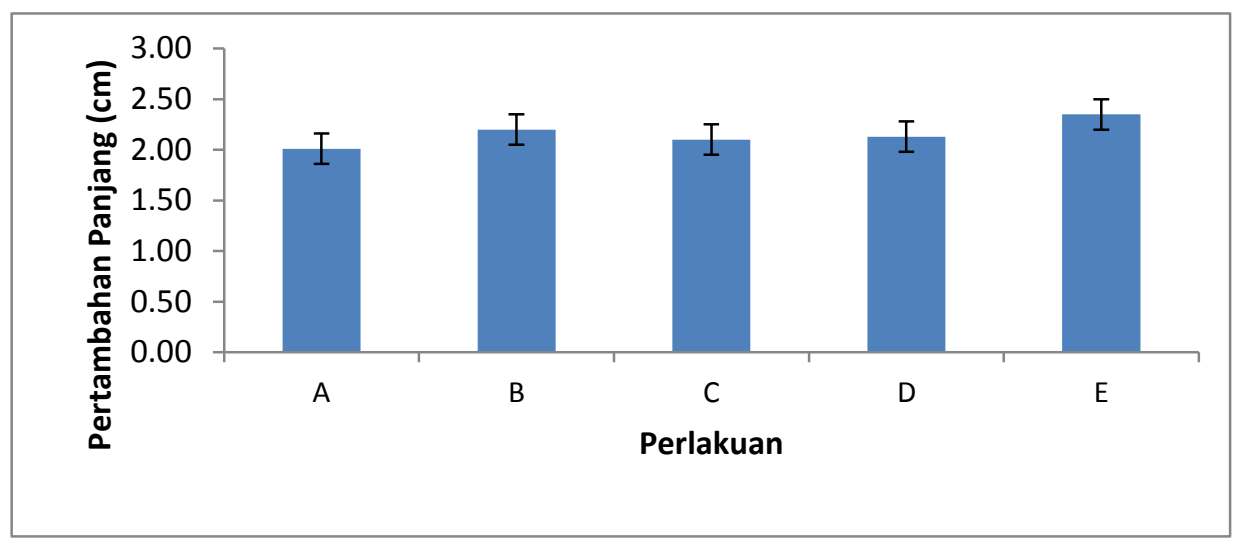

Gambar 4. Hasil Uji BNT pada Setiap Perlakuan Terhadap Pertambahan Panjang

\section{Tingkat Kelangsungan Hidup}

Data analisis tingkat kelangsungan hidup larva ikan patin selama penelitian dari masing-masing perlakuan tersaji pada Tabel 5.

Tabel 5. Tingkat Kelangsungan Hidup

\begin{tabular}{ccc}
\hline Perlakuan & $\begin{array}{c}\text { Rata-rata Kelangsungan } \\
\text { Hidup }(\boldsymbol{\%})\end{array}$ & Standar Deviasi \\
\hline A & $25,20-52,70$ & $38,95 \pm 13,75$ \\
B & $40,98-55,28$ & $48,13 \pm 7,15$ \\
C & $45,54-55,52$ & $50,53 \pm 4,99$ \\
D & $62,26-68,14$ & $65,2 \pm 2,94$ \\
E & $52,18-60,48$ & $56,33 \pm 4,15$ \\
\hline
\end{tabular}

Tingkat kelangsungan hidup larva ikan patin pada penelitian ini yang tertinggi adalah perlakuan $\mathrm{D}=$ dengan rata-rata tingkat kelangsungan hidup $62,26-68,14 \%$ yang diikuti oleh perlakuan $\mathrm{E}=52,18-60,48 \%$, perlakuan $\mathrm{C}=45,54-55,52 \%$, perlakuan $\mathrm{B}=40,98-55,28 \%$ dan perlakuan $\mathrm{A}=25,2-52,70 \%$. Tingkat kelangsungan hidup larva ikan patin dapat dipengaruhi oleh beberapa faktor antara lain sifat fisika dan kimia air. Selama percobaan dilakukan yang dominan mempengaruhi tingkat kelangsungan hidup pada saat pergantian air.

Pengkayaan nutrisi pada cacing sutera dengan kuning telur ayam kampung sebagai pakan larva ikan patin terhadap tingkat kelangsungan hidup larva patin memberikan pengaruh nyata ( $p>0.05)$. Hal ini terlihat bahwa $F$ hitung $(6,33)$ lebih besar dari pada $\mathrm{F}$ tabel $(3,06)$. Hasil uji BNT terlihat ada perbedaan nyata dari masing-masing perlakuan terhadap tingkat kelangsungan hidup larva patin sebesar $11.5 \%$ dapat dilihat pada Gambar 5. 


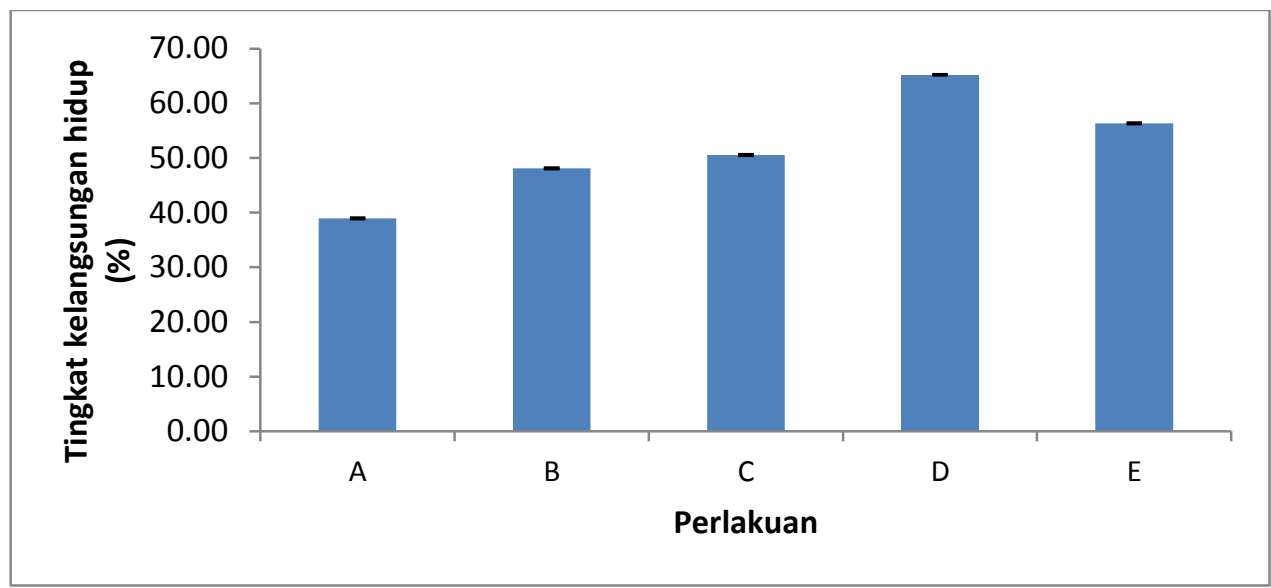

Gambar 5. Hasil Uji BNT pada Setiap Perlakuan Terhadap Tingkat

Kelangsungan Hidup

Korelasi Laju Pertumbuhan antara Pertambahan Bobot dan Panjang

Pertumbuhan adalah total energi yang diubah menjadi penyusun tubuh, kebutuhan energi ini diperoleh dari makanan. Pertumbuhan juga merupakan suatu proses pertambahan bobot maupun panjang tubuh ikan, adapun perbedaan laju pertumbuhan dapat disebabkan karena adanya pengaruh padat penebaran dan persaingan di dalam mendapatkan makanan. (Hernowo, 2001). Hubungan antara pertambahan bobot dan panjang tersaji pada Gambar 10, terjadi penurunan garis linear pada bobot perlakuan B sedangkan panjang mengalami pertambahan, hal ini terjadi adanya larva ikan terlihat kurus dan panjang sehingga tidak mengalami penambahan bobot pada saat penimbangan, kemungkinan disebabkan larva ikan mengalami penurunan nafsu makan pada tahap akhir penelitian, sehingga mengakibatkan tidak ada penambahan bobot pada larva ikan patin.

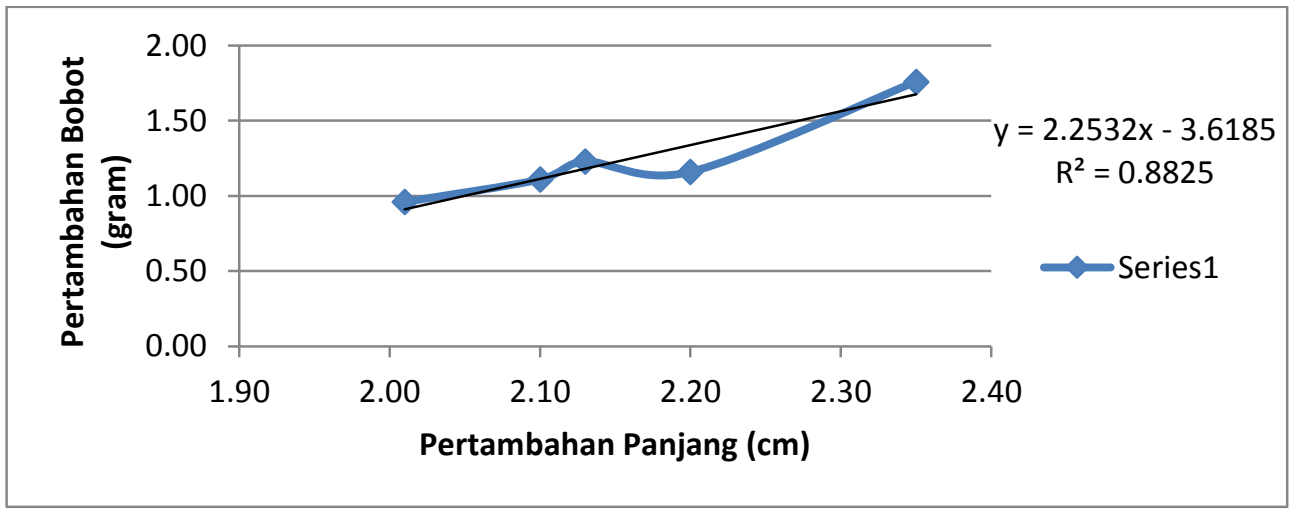

Gambar 6. Korelasi Pertumbuhan Antara Pertambahan Bobot dan Panjang 


\section{Kualitas Air}

Data kualitas air dari hasil pengukuran menunjukkan bahwa nilai dari masingmasing parameter memiliki pengaruh yang sama pada semua perlakuan. Pengukuran kualitas air di lokasi penelitian meliputi: suhu, $\mathrm{pH}$, dan DO, hasil pengukuran menunjukkan bahwa parameter kualitas air pada wadah tempat penelitian berkisar antara suhu $28^{\circ} \mathrm{C}$ sampai $29^{\circ} \mathrm{C}, \mathrm{pH} \quad 6.5$ sampai 7 dan DO 4,3 sampai $6 \mathrm{mg} / \mathrm{l}$. Ikan patin sangat toleran terhadap derajat keasaman $(\mathrm{pH})$ air. Artinya ikan ini dapat bertahan hidup baik pada kisaran $\mathrm{pH}$ 5-9. Kandungan $\mathrm{O}_{2}$ terlarut yang dibutuhkan berkisar antara 3-6 ppm, $\mathrm{CO}_{2}$ yang bisa ditoleran berkisar antara 9-20 ppm. Alkalinitasnya antara 80-250 ppm. Suhu air media pemeliharaan yang optimal berkisar antara $28-30^{\circ} \mathrm{C}$ (Khairuman dan Khairul, 2010). Selama pemeliharaan, larva ikan patin mengalami pertumbuhan pertambahan bobot dan pertambahan panjang, hal ini menunjukkan bahwa larva ikan patin dapat memanfaatkan pakan yang diberikan sebagai sumber energi.

\section{KESIMPULAN}

\section{Kesimpulan}

Pengkayaan nutrisi pada cacing sutera (Tubifex spp) dengan kuning telur ayam kampung berpengaruh positif terhadap pertumbuhan larva ikan patin. Hal ini terlihat dari perlakuan $\mathrm{E}$ dengan pertambahan bobot rata-rata $1.67-1.85 \mathrm{~g}$ dan pertambahan panjang rata-rata 2.22 $2.48 \mathrm{~cm}$. Perlakuan D menunjukkan tingkat kelangsungan hidup larva patin tertinggi 62.26 - 68.14\% sedangkan pertumbuhan pertambahan bobot dan panjang terlihat pada perlakuan E, hal ini dianggap wajar karena pada umumnya semakin rendah kepadatan ikan semakin cepat pertumbuhannya, dengan demikian cacing sutera (Tubifex spp) yang dicincang halus dan dibekukan dapat digunakan untuk pakan larva ikan patin.

\section{Saran}

Berdasarkan hasil penelitian dapat disarankan :

\section{DAFTAR PUSTAKA}

Azahari, H. 2007. Budidaya Ikan Patin. Forum Budidaya Ikan. Cianjur.

Bell, D. and Weaver, G. 2002. Commercial Chicken Meat and Egg. Kluwer Academic Publishers, United States of America.

Cahyono, B. 2010.Budidaya ikan Patin, Sepat \& Baung. Pustaka Mina. Jakarta.

Ciptanto, S. 2010. Top 10 Ikan Air Tawar. Andi. Jakarta

Djarijah A S. 1996. Pakan Ikan Alami. Yogyakarta: Kanisius.

Effendie, M.I. 1997. Biologi perikanan. Yayasan Pustaka Nusatama. Bogor $163 \mathrm{hlm}$

Effendie, M.I., 1979. Metode Biologi Perikanan. Cetakan Pertama. Yayasan Dewi Sri, Bogor.

Gomez, K.A. dan A.A. Gomes, 1995. Prosedur Statistik untuk Penelitian Pertanian, edisi kedua. Penerbit Universitas Indonesia (UI-Press). Jakarta.

Gusrina, 2008. Budidaya Ikan untuk SMK. Pusat Perbukuan Departemen Pendidikan Nasional. Jakarta. 
Hernowo. 2001. Pembenihan Patin Skala Kecil dan Besar, Solusi Permasalahan. wadaya, Jakarta. 66 hal

Khairuman dan D.Sudenda. 2002. Budidaya Ikan Patin Secara Intensif. Agro Media Pustaka. Jakarta.

Khairuman dan Khairul, 2010. Buku Pintar 15 Ikan Konsumsi, PT. Agro Media Pustaka, Jakarta.

Kordi. 2005. Budidaya Ikan Patin, Pembenihan, dan pembesaran. Yayasan Pustaka Nusatama. Yogyakarta.

Lukito A dan Surip P. 2007. Panduan Lengkap Lobster Air Tawar. Jakarta: Penebar Swadaya.

Mulyantini. 2010. Ilmu Manajemen Ternak Unggas. Gajah. Mada University Press. Yogyakarta.
Rasyaf, M., 1990. Bahan Makanan Unggas di Indonesia. Kanisius, Yogyakarta. Suprapti, M. L. 2002. Pengawetan telur : Telur Asin, tepung telur, dan telur beku. Kanisius, Yogyakarta.

Susanto, H. dan Khairul Amri. 2002. Budidaya Ikan Patin. Penebar Swadaya. Jakarta

Yamamoto at al. 1997. Hen Eggs, CRC Perss. New York.

Yamaoka. L. H. and B.T. Scheer. 1970. Chemistry of growth and development in crustaceas. In : chemical Vol. 5 Artrophoda, part A.M Florkin and B.T. Scheer (Eds). Academic Press. New York : 321-340 